\title{
Sir Julian Huxley FRS
}

Doyen of British conservationists, Sir Julian Huxley FRS, who died on February 15, had been a Vice President of the Fauna Preservation Society since 1962 , and an ordinary member since 1931 . He had a lifelong interest in conserving the wildlife of Africa, and travelled widely there. Perhaps his greatest contribution was to act as midwife to the infant International Union for the Protection of Nature (now IUCN), while he was Director-General of Unesco in the late 40s. He played a similar part for the pioneeringly successful Nature Conservancy in Britain, which was born out of the report of the Wild Life Conservation Special Committee, of which he was Chairman, in 1947.

It was, however, as a naturalist and observer of wildlife that Julian Huxley achieved his highest peaks. His pioneer field studies of the behaviour of the great crested grebe and the redshank before the First World War founded a whole new branch of science. Most of all, he just enjoyed watching wildlife, whether it was birds in his Hampstead garden or zebras on the Serengeti plains. His active mind threw itself into his watching with an enthusiasm that brought fresh insights and heightened enjoyment for his companions. A day in the field in his company was a liberal education in itself.

\section{Endangered Species Trade in Britain}

Further news of Britain's pioneer effort in controlling the trade in endangered species is now available in the shape of the ninth annual report of the Advisory Committee on the Animals (Restriction of Importation) Act 1964. During 1973 responsibility for the committee passed from the Department of Education and Science to that of the Environment. That the mechanism of control is working in the way intended is shown by the following comment:

The number of applications for the import of chimpanzees continued to rise in $1973 . .$. the Committee has kept under constant review the need for importation of chimpanzees from the wild, bearing in mind reports from various sources that sufficient chimpanzees are now bred in captivity to meet the genuine needs for this species in this country. The Committee is still unable to conclude that all further importation from the wild should be suspended, but each application for importation is very closely scrutinised to determine whether it should be allowed, or whether the applicant should be advised to seek captive-born animals and if necessary wait until such are available. In any case, the Committee needs to be satisfied that every effort has been made to meet approved requirements from captive-born sources. The Committee is particularly concerned ... at the number of applications for chimpanzees for research purposes. It will continue to scrutinise such applications very closely before recommending the issue of licences.

The Committee also regrets that the Medical Research Council continues to fail to grapple with the general problem of primates for research. The Council has so far come to no conclusions on the important study of the techniques of breeding animals for research, made on its behalf, but not yet even approved for publication.

Total numbers of animals imported into the UK in 1973 were: 3 marsupials, 11,647 primates (42 great apes), 4 rhinoceroses, 13 tapirs, 23 wild members of the cat family, 748 iguanid lizards and 114,223 tortoises and terrapins. Both Old World monkeys and land tortoises showed a welcome fall from the 1972 figures, respectively from 11,557 to 9,960 and from 207,675 to 67,605 . 


\section{Conservation in Spain}

The Spanish Government passed a decree in October 1973 giving total protection to six mammal species and one subspecies. They are bear Ursus arctos, stoat Mustela erminea, otter Lutra lutra, mongoose Herpestes ichneumon, wild cat Felis sylvestris, lynx Felis lynx, and the Spanish ibex Capra ibex pyrenaica. Also protected are all raptors (26 diurnal and 7 nocturnal), but not vultures, which are still snared, 11 other birds, and three reptiles - chameleon and two tortoises, Testudo graeca and T. hermanni.

The FPS member who sends this list, James MacIvor of Torreviejo, says that members of the newly founded Associacion de Naturalistas del Sureste (ANSE) have discovered several good tortoise areas in southern Murcia and have 'made a point of informing the locals that the turtle business is now finished'. In Alicante, he says, T. graeca is no longer displayed on stalls in village markets as it used to be, or in pet shops, except in the provincial capital. ANSE is also engaged in the search for information, especially among old village people, about the rare Mediterranean monk seal.

The protection laws obviously cannot work unless people co-operate, and education at all levels is urgently needed, as Arturo Sarro points out in an article in $\mathrm{La}$ Vanguardia Española. He also draws attention to the widespread commercial planting in Spain of quick-growing eucalyptus trees, which turn mountain sides into deserts. They make little humus, take a great deal of water, and prevent undergrowth; the inevitable result is soil erosion.

\section{New Measures in Bolivia}

The Bolivian Government, in December 1973, issued a decree banning the capture and marketing of either products or live specimens of macaws, toucans, cormorants, Muscovy duck, helmeted and horned curassows Pauxi pauxi and $\boldsymbol{P}$. unicornis, and cardinals. The hunting and capture of rheas was also forbidden.

Reporting this Dr Armando Cardozo also reports an earlier decree which created a second National Reserve for Andean fauna in Lipez, in south-west Bolivia. This includes Laguna Colorado, the breeding ground of the rare James's flamingo, and a radius of $10 \mathrm{~km}$. all round the lake. The first such reserve for Andean fauna was Ulla Ulla, created primarily to protect vicuña as well as a great variety of other animals including possibly spectacled bear.

\section{Marine Parks of the World}

A world list of all established and all proposed marine parks and reserves is published in a paper on Marine Parks in Environmental Conservation, Autumn 1974, by Møna Björklund, Executive Officer of IUCN's Commission on Ecology. The increasingly urgent need to protect wildlife in the sea and create marine parks and reserves has led IUCN/WWF to give high priority to identifying the important areas and advising on how best to protect them, and to evaluate existing marine parks and reserves.

\section{Mauritius Kestrels Success}

One of the only two surviving wild pairs of Mauritius kestrels has raised two or three young, believed to be the first successful breeding for two years. The pair nested in a cliff hole where the nest was safe from the two main predators, monkeys and rats. The first attempt at captive breeding failed when a mercury vapour switch controlling the incubator temperature exploded, killing the only young bird to hatch. 